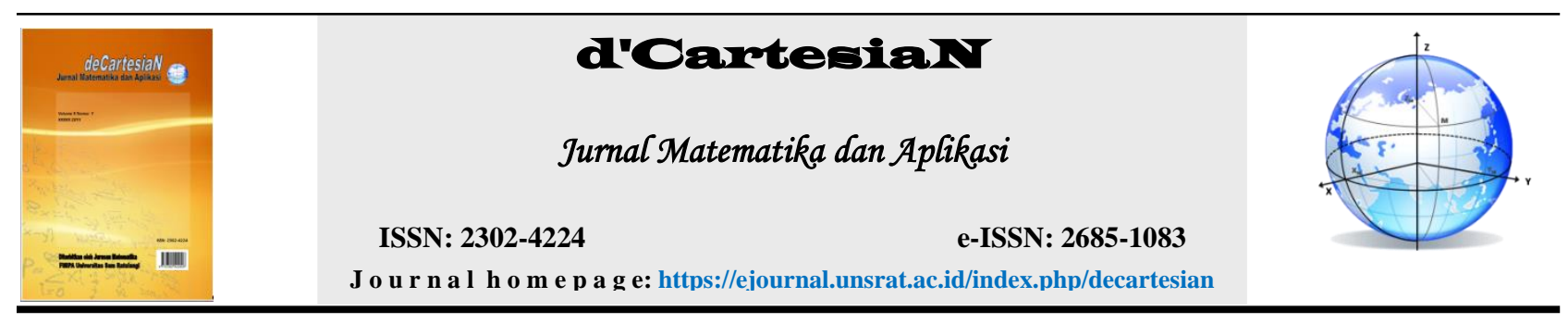

\title{
Analisis Sistem Antrian Di PT. Bank Negara Indonesia (Persero) Tbk. Kantor Cabang Manado
}

\author{
Ripit Budiman', Djoni Hatidja1, Marline S Paendong1*
}

${ }^{1}$ Jurusan Matematika-Fakultas Matematika dan Ilmu Pengetahuan Alam-Universitas Sam Ratulangi Manado, Indonesia

*Corressponding author : marline_paendong@yahoo.com

\begin{abstract}
A B S T R A K
Tujuan penelitian ini adalah untuk mengetahui model antrian dan menentukkan karakteristik panjang antrian di PT. Bank Negara Indonesia (Persero) Tbk. Kantor Cabang Manado. Pengambilan data dilakukan selama 5 hari. Model sistem antrian yang digunakan adalah Model B:M/M/S (Multiple Channel Query System atau Model Antrian Jalur Berganda), jumlah teller yang beroperasi ada 7 teller dan pelayanan yang digunakan adalah First Come First Served, tingkat kedatangan berdistribusi Poisson, dan waktu pelayanan berdistribusi Eksponensial. Hasil penelitian menunjukkan jumlah kedatangan rata-rata adalah 42 nasabah yang datang per jam, dan jumlah rata-rata nasabah yang dilayani adalah 9 nasabah dilayani per jam. Tidak adanya pelanggan dalam sistem 0.01, jumlah pelanggan rata-rata dalam sistem sebanyak 6 nasabah, waktu yang dihabiskan nasabah dalam antrian dan sedang dilayani 89 menit, jumlah rata-rata nasabah yang menunggu dalam antrian untuk dilayani ada 1 nasabah, dan waktu rata-rata yang dihabiskan nasabah untuk menunggu dalam antrian 1-2 menit.
\end{abstract}

\section{INFO ARTIKEL}

Diterima : 9 Oktober 2019

Diterima setelah revisi : 23 Oktober 2019

Tersedia online : 28 Oktober 2019

\section{Kata Kunci:}

Sistem Antrian

Multi Channel Query System

Antrian Jalur Berganda

\begin{abstract}
A B S T R A C T
The purpose of this research was to determine the queuing model and determine the characteristic length of the queue at PT. Bank Negara Indonesia Branch Office of Manado. Data collection was carried out for 5 days. The queuing system model used is the B:M/M/S Model (Multiple Channel Query System), the number of tellers that operating there are 7 tellers and the service used is First Come First Served, the arrival rate is Poisson distribution, and the service time is Exponential distribution. The result of this research shows the average number of arrivals is 42 customers who come per hour, and the average number of customers served is 9 customers served per hour. There are no customers in the 0.01 system, the average number of customers in the system is 6 customers, the time customers spend in the queue and is being served is 89 minutes, the average number of customers waiting in the queue to be served is 1 customer, and the average time of customers spend for waiting in the queue is 1-2 minutes.
\end{abstract}

\section{ARTICLE INFO}

Accepted : 9 october 2019

Accepted after revision : 23 october 2019

Available online : 28 October 2019

\section{Keywords: \\ Queue System \\ Multi Channel Query System \\ Multiple Line Queues}

\section{PENDAHULUAN}

Dalam kehidupan manusia pasti kita pernah mengalami yang namanya antrian, terlebih khusus di PT. Bank Negara Indonesia (Persero) Tbk. Kantor Cabang Manado ada nasabah yang datang di bank tersebut yang membutuhkan pelayanan. Pada zaman modern sekarang pasti semua dituntut untuk serba cepat. Hal ini dikarenakan bertambahnya jumlah populasi penduduk di dunia, perkembangan teknologi dan pembangunan yang ada disegala bidang juga berlangsung begitu cepat.

Perusahaan dibidang jasa maupun manufaktur harus mampu memberikan pelayanan yang cepat serta terbaik sesuai dengan keinginan pelanggan untuk memenuhi kebutuhannya mengingat akan jumlah populasi yang banyak tersebut. Perusahaan jasa 
merupakan perusahaan yang memiliki kegiatan atau manfaat yang menawarkan pada suatu pihak kepada pihak lain dan pada dasarnya tidak berwujud, serta tidak menghasilkan kepemilikan sesuatu [1].

Suatu antrian terjadi akibat ketidak seimbangan rasio jumlah pelanggan dengan jumlah fasilitas pelayanan. Menunggu untuk di layani dianggap menyebabkan pelanggan frustasi, marah, dan cemas [2]. Semakin lama pelanggan percaya bahwa ia sedang mengantri, semakin buruk penilaian pelanggan tersebut terhadap pelayanan yang diterima [3].

Pada penelitian sebelumnya yaitu deskripsi sistem antrian pada Bank SULUT Manado [4], deskripsi sistem antrian pada klinik dokter spesialis penyakit dalam [5], dan model antrian pada sistem pembayaran di Golden Pasar Swalayan Manado [6].

Dalam sistem antrian, kecepatan waktu pelayanan mempengaruhi panjangnya antrian. Bila perusahaan lambat dalam proses pelayanan, maka antrian akan panjang. Sebaliknya, jika perusahaan dapat memberi pelayanan terbaik dalam waktu singkat, maka antrian yang terbentuk tidak akan terlalu panjang.

\section{Teori Antrian}

Teori antrian (queuing theory) merupakan studi matematika dari antrian atau kejadian garis tunggu dari pelanggan yang memerlukan layanan dari sistem yang ada [7]. Sebuah organisasi harus berusaha memberikan pelayanan agar pelanggan tidak mengantri terlalu lama. Biasanya ada biaya bagi organisasi untuk menambah fasilitas layanan. Layanan yang cepat akan mempertahankan pelanggan dan jangka panjang meningkatkan keuntungan perusahaan.

Sebuah sistem antrian adalah suatu himpunan pelanggan, pelayan dan suatu antrian yang mengatur kedatangan pelanggan dan pemprosesan masalahnya. Pelanggan yang tiba dapat bersifat tetap atau tidak tetap untuk memperoleh pelayanan. Apabila pelanggan yang tiba dapat langsung masuk kedalam sistem pelayanan maka pelanggan tersebut langsung dilayani, sebaliknya jika harus menunggu maka mereka harus membentuk antrian hingga tiba waktu pelayanan [8].

\section{Sistem Antrian}

Sistem antrian adalah kedatangan pelanggan untuk mendapatkan pelayanan. Fenomena menunggu adalah hasil langsung dari keacakan dalam operasi sarana pelayanan. Secara umum, kedatangan pelanggan dan waktu perbaikan tidak diketahui sebelumnya, karena jika dapat diketahui, pengoperasian sarana tersebut dapat dijadwalkan sedemikian rupa sehingga akan sepenuhnya menghilangkan keharusan untuk menunggu.

\section{Struktur Antrian}

Ada empat model struktur antrian dasar yang umum terjadi dalam seluruh sistem antrian:

1. Satu Jalur, Satu Tahap (Single Channel, Single Phase)

Sistem antrian satu jalur satu tahap berarti bahwa dalam sistem tersebut hanya terdapat satu pemberi layanan serta satu jenis layanan yang diberikan, sehingga yang telah menerima pelayanan dapat langsung keluar dari sistem antrian.

Sistem Antrian :

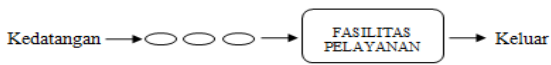

Gambar 2. Satu Jalur, Satu Tahap.

2. Satu Jalur, Banyak Tahap (Single Channel, Multi Phase)

Sistem antrian satu saluran banyak tahap berarti dalam sistem antrian tersebut terdapat lebih dari satu jenis layanan yang diberikan, tetapi dalam setiap jenis layanan hanya terdapat satu pemberi layanan. Sistem antrian :

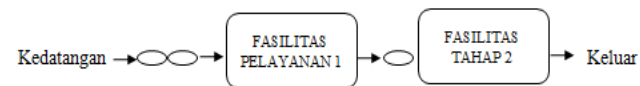

Gambar 3. Satu Jalur, Banyak Tahap.

\section{Banyak Jalur, Satu Tahap (Multi Channel, Single} Phase)

Sistem antrian banyak saluran satu tahap adalah sistem antrian dimana terdapat satu jenis layanan dalam sistem antrian tersebut, namun terdapat lebih dari satu pemberi layanan.

Sistem antrian :

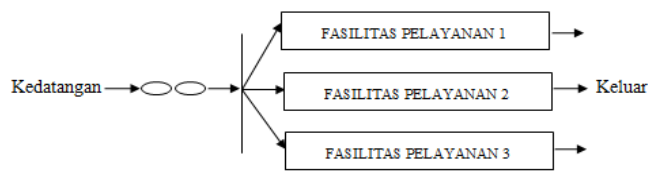

Gambar 4. Banyak Jalur, Satu Tahap.

\section{Banyak Jalur, Banyak Tahap (Multi Channel, Multi} Phase)

Sistem antrian banyak saluran banyak tahap adalah sistem antrian dimana terdapat lebih dari satu jenis layanan dan terdapat lebih dari satu pemberi layanan dalam setiap jenis layanan [9].

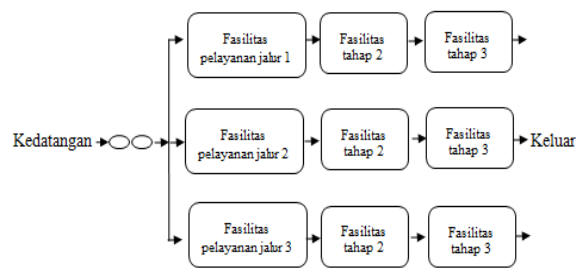

Gambar 5. Banyak Jalur, Banyak Tahap.

\section{Pola Kedatangan dan Lama Pelayanan}

1. Pola Kedatangan

Fungsi peluang poisson digunakan untuk menggambarkan tingkat kedatangan dengan asumsi bahwa jumlah kedatangan adalah acak dan kedatangan pelanggan antar interval waktu saling tidak mempengaruhi. Peluang tepat terjadinya $x$ kedatangan dalam sebaran poisson dapat diketahui dengan menggunakan rumus:

$$
P(x)=\frac{\lambda^{x} e^{-\lambda}}{x !}
$$

Keterangan:

$\mathrm{P}(\mathrm{x})=$ Peluang bahwa ada $\mathrm{x}$ kedatangan dalam sistem

$\lambda=$ Tingkat kedatangan rata-rata

$\mathrm{e}=$ Bilangan Navier $(\mathrm{e}=\mathbf{2} .71828183)$ 
$\mathrm{x}=$ Variabel acak diskrit yang menyatakan banyaknya kedatangan perinterval waktu

\section{Uji Kesesuaian Poisson}

Untuk menghitung nilai $\chi^{2}$ dari data pengamatan pada $h_{1}, h_{2}, \cdots, h_{5}$ terlebih dahulu ditentukan nilai waktu kedatangan yang diharapkan dengan menggunakan rumus sebaran Poisson dan mengambil nilai $t=1$ pada rumus sebaran Poisson.

Untuk menentukan nilai $\chi^{2}$ maka digunakan rumus:

$$
\chi^{2}=\sum_{i=1}^{k} \frac{\left(\lambda_{i}-\bar{\lambda}\right)^{2}}{\bar{\lambda}}
$$

Dimana:

$\lambda_{i}=$ Tingkat kedatangan rata-rata pada waktu ke- $i$

$\bar{\lambda}=$ Rata-rata tingkat kedatangan

$\mathrm{k}=$ Banyaknya pengamatan

Kriteria keputusan dilakukan dengan terima rata-rata kedatangan bersebaran Poisson apabila $\chi_{\text {hitung }}^{2} \leq$ $\chi^{2}{ }_{\text {tabel }}$ dalam hal lain keputusan ditolak.

\section{Lama Pelayanan}

Lama pelayanan yang dihitung sejak kedatangan pelanggan dalam sistem antrian sampai selesai pelayanan mengikuti sebaran Eksponensial. Ini bisa dilakukan dengan membandingkan sampel waktu pelayanan yang sebenarnya dengan waktu pelayanan yang diharapkan berdasarkan rumus sebagai berikut:

$$
f(t)=\mu e^{-\mu t}
$$

Keterangan:

$\mu=$ Rata-rata tiap pelayanan (unit pelayanan per unit waktu)

$\mathrm{e}=$ Bilangan Navier $(\mathrm{e}=\mathbf{2 . 7 1 8 2 8 1 8 3})$

$\mathrm{t}=$ Waktu lamanya pelayanan (unit pelayanan per unit waktu)

\section{Uji Kesesuaian Eksponensial}

Untuk menghitung nilai $\chi^{2}$ dari data pengamatan pada $h_{1}, h_{2}, \cdots, h_{5}$ terlebih dahulu ditentukan nilai waktu pelayanan yang diharapkan dengan menggunakan rumus sebaran Eksponensial dan menggunakan nilai $t=$ 1.

Untuk menentukan nilai $\chi^{2}$ maka digunakan rumus:

$$
\chi^{2}=\sum_{i=1}^{k} \frac{\left(\mu_{i}-\mu_{i \text { harapan }}\right)^{2}}{\mu_{i \text { harapan }}}
$$

Keterangan:

$\mu_{i}=$ Rata-rata waktu pelayanan pada waktu ke- $i$

$\mu_{i \text { harapan }}=$ Rata-rata waktu pelayanan harapan pada

waktu ke- $i$

$\mathrm{k}$ = Banyaknya pengamatan

Kriteria keputusan dilakukan dengan terima rata-rata pelayanan bersebaran Eksponensial apabila $\chi_{\text {nitung }}^{2} \leq$ $\chi_{\text {tabel }}^{2}$ dalam hal lain keputusan ditolak.

\section{Model Antrian}

Beragam model antrian dapat digunakan dibidang Manajemen Operasi. Empat model yang paling sering digunakan oleh perusahaan dengan menyesuaikan situasi dan kondisi masing-masing. Dengan mengoptimalkan sistem pelayanan, dapat ditentukan waktu pelayanan, jumlah saluran antrian, dan jumlah pelayanan yang tepat dengan menggunakan model-model antrian. Empat model antrian tersebut adalah sebagai berikut.

1. Model A: M/M/1 (Single Channel Query System atau Model Antrian Jalur Tunggal)

Dalam situasi ini, kedatangan membentuk satu jalur tunggal untuk dilayani oleh stasiun tunggal. Rumus antrian untuk model A adalah

$$
L s=\frac{\lambda}{\mu-\lambda}
$$

Keterangan:

$\lambda=$ Jumlah kedatangan rata-rata per satuan waktu $\mu=$ Jumlah rata-rata yang dilayani per satuan waktu Ls = Jumlah pelanggan rata-rata dalam sistem

1) Jumlah waktu rata-rata yang dihabiskan dalam sistem (Waktu menunggu ditambah waktu pelayanan)

$$
W s=\frac{1}{\mu-\lambda}
$$

2) Jumlah unit rata-rata yang menunggu dalam antrian

$$
L q=\frac{\lambda^{2}}{\mu(\mu-\lambda)}
$$

3) Waktu rata-rata antrian dalam sistem

$$
W q=\frac{\lambda}{\mu(\mu-\lambda)}
$$

4) Faktor utilisasi sistem (Populasi fasilitas pelayanan sibuk)

$$
\rho=\frac{\lambda}{\mu}
$$

5) Probabilitas terdapat o unit dalam sistem (Yaitu unit pelayanan kosong)

$$
\text { Po }=1-\frac{\lambda}{\mu}
$$

6) Probabilitas terdapat lebih dari sejumlah $\mathbf{k}$ unit dalam sistem, dimana $\mathbf{n}$ adalah jumlah unit dalam sistem.

$$
\mathrm{P}_{\mathrm{n}>\mathrm{k}}=\left[\frac{\lambda}{\mu}\right]^{K+1}
$$

2. Model B: M/M/S (Multiple Channel Query System atau Model Antrian Jalur Berganda)

Sistem antrian jalur berganda terdapat dua atau lebih jalur atau stasiun pelayanan yang tersedia untuk menangani pelanggan yang akan datang. Asumsi bahwa pelanggan yang menunggu pelayanan membentuk satu jalur yang akan dilayani pada stasiun pelayanan yang tersedia pertama kali pada saat itu. Pelayanan dilakukan secara first-come, first-served, dan semua stasiun pelayanan yang sama. Rumus antrian untuk model B adalah sebagai berikut.

1) Probabilitas terdapat o orang dalam sistem (Tidak adanya pelanggan dalam sistem).

$$
\text { Po }=\frac{1}{\left[\sum_{n=0}^{M-1} \frac{1}{n !}\left(\frac{\lambda}{\mu}\right)^{n}\right]+\frac{1}{M !}\left(\frac{\lambda}{\mu}\right)^{M} \frac{M \mu}{M \lambda-\mu}}
$$

2) Jumlah pelanggan rata-rata dalam sistem

$$
L s=\frac{\lambda \mu(\lambda / \mu)^{M}}{(M-1) !(M \mu-\lambda)^{2}} P o+\frac{\lambda}{\mu}
$$

3) Waktu rata-rata yang dihabiskan seorang pelanggan dalam antrian dan sedang dilayani (Dalam sistem)

$$
W s=\frac{L s}{\lambda}
$$

4) Jumlah orang atau unit rata-rata yang menunggu dalam antrian 


$$
L q=L s-\frac{\lambda}{\mu}
$$

5) Waktu rata-rata yang dihabiskan oleh seorang pelanggan atau unit untuk menunggu dalam antrian

$$
W q=\frac{L q}{\lambda}
$$

Keterangan:

$\mathrm{M}=$ Jumlah jalur yang terbuka

$\lambda=$ Jumlah kedatangan rata-rata per satuan waktu

$\mu=$ Jumlah rata-rata orang yang dilayani per satuan waktu

$\mathrm{n}=$ Jumlah pelanggan

Po $=$ Probabilitas terdapat o orang dalam sistem

Ls = Jumlah pelanggan rata-rata dalam sistem

Ws = Waktu rata-rata yang dihabiskan pelanggan dalam sistem

$\mathrm{Lq}=$ Jumlah unit rata-rata yang menunggu dalam antrian

$\mathrm{Wq}=$ Waktu rata-rata yang dihabiskan pelanggan untuk menunggu dalam antrian

3. Model C: M/D/1 (Constant Service atau Waktu Pelayanan Konstan)

Beberapa sistem memiliki waktu pelayanan yang tetap, dan bukan berdistribusi eksponensial seperti biasanya. Rumus antrian untuk model $\mathrm{C}$ adalah sebagai berikut.

1) Panjang antrian rata-rata

$$
L q=\frac{x^{2}}{2 \mu(\mu-\lambda)}
$$

2) Waktu menunggu dalam antrian rata-rata

$$
W q=\frac{\lambda}{2 \mu(\mu-\lambda)}
$$

3) Jumlah pelangan dalam sistem rata-rata

$$
L s=L q+\frac{\lambda}{\mu}
$$

4) Waktu tunggu rata-rata dalam sistem

$$
W s=W q+\frac{1}{\mu}
$$

4. Model D: (Limited Population atau Populasi Terbatas)

Model ini berbeda dengan ketiga model yang lain, karena saat ini terdapat hubungan saling ketergantungan antara panjang antrian dan tingkat kedatangan. Ketika terdapat sebuah populasi pelanggan potensial yang terbatas bagi sebuah fasilitas pelayanan, maka model antrian berbeda harus dipertimbangkan.

$$
\text { 1) Faktor pelayanan }
$$

$$
x=\frac{T}{T+U}
$$

2) Jumlah antrian rata-rata

$$
L=N(1-F)
$$

3) Waktu tunggu rata-rata

$$
W=\frac{L(T+U)}{N-L} \quad=\frac{T(1-F)}{X F}
$$

4) Jumlah pelayanan rata-rata

$$
J=N F(1-X)
$$

5) Jumlah dalam pelayanan rata-rata

$$
H=F N X
$$

6) Jumlah populasi

$$
N=J+L+H
$$

Keterangan:

$\mathrm{D}=$ Probabilitas sebuah unit harus menunggu didalam antrian

$\mathrm{F}=$ Faktor efesiensi
$\mathrm{H}=$ Rata-rata jumlah unit yang sedang dilayani

$\mathrm{J}=$ Rata-rata unit yang tidak berada dalam antrian

$\mathrm{L}=$ Rata-rata jumlah unit yang menunggu untuk dilayani

$\mathrm{M}=$ Jumlah jalur pelayanan

$\mathrm{N}$ = Jumlah pelanggan potensial

$\mathrm{T}=$ Waktu pelayanan rata-rata

$\mathrm{U}=$ Waktu rata-rata antara unit yang membutuhkan pelayanan

$\mathrm{W}=$ Waktu rata-rata sebuah unit menunggu dalam antrian

$\mathrm{X}=$ Faktor pelayanan

\section{METODOLOGI PENELITIAN \\ Waktu dan Tempat Penelitian}

Penelitian berlangsung selama 5 bulan yaitu pada bulan April 2019 sampai dengan bulan Agustus 2019. Penelitian dilaksanakan di PT. Bank Negara Indonesia (Persero) Tbk. Kantor Cabang Manado dan untuk analisis data dilakukan di Laboratorium Statistika Jurusan Matematika FMIPA Universitas Sam Ratulangi Manado.

\section{Metode Pengumpulan Data}

Data dalam penelitian ini menggunakan data primer yang diperoleh dari pengamatan langsung di PT. Bank Negara Indonesia (Persero) Tbk. Kantor Cabang Manado Jl. Dotulolong Lasut No. 1 Manado 95122, Sulawesi Utara. Pengambilan data dilakukan selama 5 hari yaitu mulai hari senin-jumat pada tanggal o8 Juli 2019 sampai dengan 12 Juli 2019, pengamatan dimulai pukul 10.00-12.00 WITA.

\section{Metode Analisis Data}

i. Menentukkan tingkat kecepatan kedatangan rata-rata nasabah

ii. Menentukkan rata-rata kecepatan waktu pelayanan dengan menggunakan rumus:

$$
\mu\left(h_{i}\right)=\frac{1}{\left(\frac{h_{1}+h_{2}+\cdots+h_{n}}{n}\right)}
$$

dan menghitung nilai harapan dengan rumus: $f(t)=\mu e^{-\mu t} ; t=1$.

iii. Uji hipotesis

Uji Kesesuaian Poisson:

$$
\chi^{2}=\sum_{i=1}^{k} \frac{\left(\lambda_{i}-\bar{\lambda}\right)^{2}}{\bar{\lambda}}
$$

Uji Kesesuaian Ekponensial:

$$
\chi^{2}=\sum_{i=1}^{k} \frac{\left(\mu_{i}-\mu_{i \text { harapan }}\right)^{2}}{\mu_{i \text { harapan }}}
$$

iv. Analisis sistem antrian dengan menggunakan model antrian jalur berganda

1) Probabilitas terdapat o orang dalam sistem (Tidak adanya pelanggan dalam sistem).

$$
P o=\frac{1}{\left[\sum_{n=0}^{M-1} \frac{1}{n !}\left(\frac{\lambda}{\mu}\right)^{n}\right]+\frac{1}{M !}\left(\frac{\lambda}{\mu}\right)^{M} \frac{M \mu}{M \lambda-\mu}}
$$

2) Jumlah pelanggan rata-rata dalam sistem

$$
L s=\frac{\lambda \mu(\lambda / \mu)^{M}}{(M-1) !(M \mu-\lambda)^{2}} P o+\frac{\lambda}{\mu}
$$


3) Waktu rata-rata yang dihabiskan seorang pelanggan dalam antrian dan sedang dilayani (Dalam sistem)

$$
W s=\frac{L s}{\lambda}
$$

4) Jumlah orang atau unit rata-rata yang menunggu dalam antrian

$$
L q=L s-\frac{\lambda}{\mu}
$$

5) Waktu rata-rata yang dihabiskan oleh seorang pelanggan atau unit untuk menunggu dalam antrian

$$
W q=\frac{L q}{\lambda}
$$

\section{Diagram Alur Penelitian}

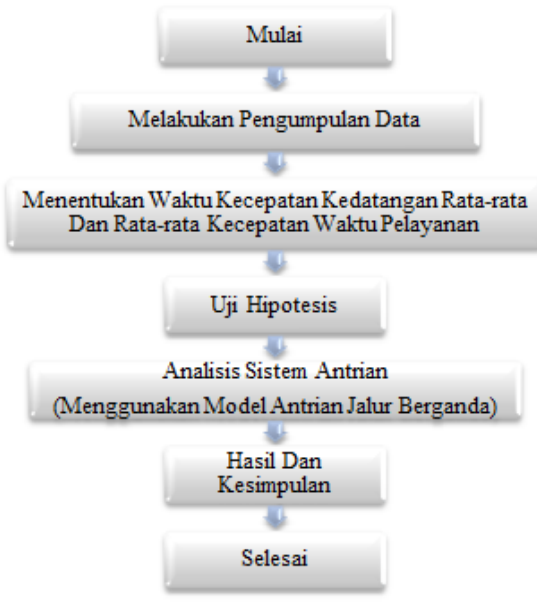

Gambar 6. Diagram Alur Penelitian

\section{HASIL DAN PEMBAHASAN}

\section{Sistem Antrian Di PT. BNI (Persero) Tbk. Kantor}

\section{Cabang Manado}

\section{Struktur Sistem Pelayanan}

Struktur sistem pelayanan di PT. Bank Negara Indonesia (Persero) Tbk. Kantor Cabang Manado dalam proses pelayanannya dapat dilihat pada gambar berikut:

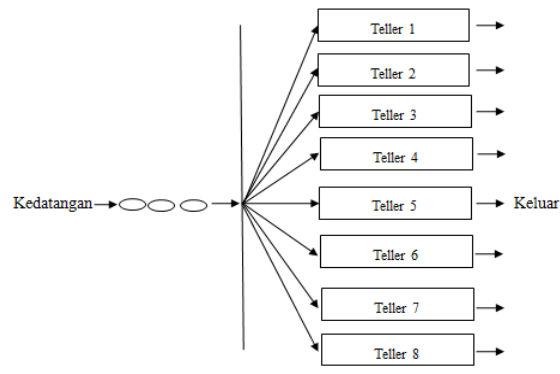

Gambar 7. Struktur Sistem Pelayanan

Maka, struktur antrian yang digunakan dalam penelitian ini adalah menggunakan Multi Channel, Single Phase atau banyak jalur satu tahap.

2. Tingkat Kedatangan Nasabah

Uji kesesuaian Poisson :

Tabel 1. Rata-rata Kecepatan Kedatangan Nasabah

\begin{tabular}{|c|c|c|c|c|c|c|c|}
\hline Hari & Senin & Selasa & Rabu & Kamis & Jumat & Total & $\bar{\lambda}$ \\
\hline$\lambda$ & 0.758 & 0.775 & 0.716 & 0.525 & 0.733 & 3.507 & 0.701 \\
\hline
\end{tabular}

Dari hasil rata-rata kecepatan kedatangan nasabah per hari pada tabel 1, diketahui bahwa kecepatan kedatangan yang paling besar pada hari selasa yaitu o.775 nasabah per menit sedangkan kecepatan kedatangan yang paling kecil pada hari kamis yaitu 0.525 nasabah per menit.

Maka untuk menentukan nilai $\chi^{2}$ digunakan rumus berikut:

$\chi^{2}=\sum_{i=1}^{k} \frac{\left(\lambda_{i}-\bar{\lambda}\right)^{2}}{\bar{\lambda}}$

$\chi^{2}=\frac{0.04095}{0.701}$

$\chi^{2}=0.058$

Berdasarkan nilai batas kritis $\chi^{2}$ dengan taraf nyata $\alpha=$ 0.05 dan $k=5$

Maka $\chi_{(1-\alpha)(k-1)}^{2}=\chi_{0.95(4)}^{2}=0.711$

Sehingga, $\chi_{\text {hitung }}^{2} \leq \chi_{\text {tabel }}^{2}=0.058 \leq 0.711$

Maka diterima asumsi bahwa pola kedatangan nasabah berdistribusi poisson.

H0 : Data yang menyebar dengan sebaran poisson

H1 : Data yang tidak mengikuti sebaran poisson

3. Waktu Pelayanan Nasabah

Uji kesesuaian eksponensial :

Tabel 2. Rata-rata Kecepatan Pelayanan Nasabah Pada Teller I

\begin{tabular}{|c|c|c|c|c|c|}
\hline Hari & Senin & Selasa & Rabu & Kamis & Jumat \\
\hline$\mu$ & 0.149 & 0.208 & 0.094 & 0.254 & 0.188 \\
\hline$\mu_{\text {harapan }}$ & 0.128 & 0.168 & 0.085 & 0.197 & 0.155 \\
\hline
\end{tabular}

Maka dari data tabel 2 untuk menentukan nilai $\chi^{2}$ digunakan rumus berikut:

$\chi^{2}=\sum_{i=1}^{k} \frac{\left(\mu_{i}-\mu_{\text {harapan }}\right)^{2}}{\mu_{\text {harapan }}}$

$\chi^{2}=\frac{0.00646}{0.733}$

$\chi^{2}=0.009$

Berdasarkan nilai batas kritis $\chi^{2}$ dengan taraf nyata $\alpha=$ 0.05 dan $k=5$

Maka $\chi_{(1-\alpha)(k-1)}^{2}=\chi^{2}{ }_{0.95(4)}=0.711$

Sehingga, $\chi_{\text {hitung }}^{2} \leq \chi_{\text {tabel }}^{2}=0.009 \leq 0.711$

Maka diterima asumsi bahwa pola pelayanan nasabah pada teller I berdistribusi eksponensial. H0 : Data yang menyebar dengan sebaran eksponensial H1 : Data yang tidak mengikuti sebaran eksponensial

Tabel 3. Rata-rata Kecepatan Pelayanan Nasabah Pada Teller II

\begin{tabular}{|c|c|c|c|c|c|}
\hline Hari & Senin & Selasa & Rabu & Kamis & Jumat \\
\hline$\mu$ & 0.239 & 0.178 & 0.283 & 0.171 & 0.150 \\
\hline$\mu_{\text {harapan }}$ & 0.188 & 0.148 & 0.213 & 0.144 & 0.129 \\
\hline
\end{tabular}

Dari data tabel 3 maka:

$\chi^{2}=\sum_{i=1}^{k} \frac{\left(\mu_{i}-\mu_{\text {harapan }}\right)^{2}}{\mu_{\text {harapan }}}$

$\chi^{2}=\frac{0.009571}{0.822}$ 
$\chi^{2}=0.011$

Berdasarkan nilai batas kritis $\chi^{2}$ dengan taraf nyata $\alpha=$ 0.05 dan $k=5$

Maka $\chi_{(1-\alpha)(k-1)}^{2}=\chi^{2}{ }_{0.95(4)}=0.711$

Sehingga, $\chi_{\text {hitung }}^{2} \leq \chi_{\text {tabel }}^{2}=0.011 \leq 0.711$

Maka diterima asumsi bahwa pola pelayanan nasabah di teller II berdistribusi eksponensial.

H0 : Data yang menyebar dengan sebaran eksponensial

H1 : Data yang tidak mengikuti sebaran eksponensial

Tabel 4. Rata-rata Kecepatan Pelayanan Nasabah Pada Teller IV

\begin{tabular}{|c|c|c|c|c|c|}
\hline Hari & Senin & Selasa & Rabu & Kamis & Jumat \\
\hline$\mu$ & 0.255 & 0.176 & 0.109 & 0.110 & 0.171 \\
\hline$\mu_{\text {harapan }}$ & 0.197 & 0.147 & 0.096 & 0.098 & 0.144 \\
\hline
\end{tabular}

Dari data tabel 4 maka:

$\chi^{2}=\sum_{i=1}^{k} \frac{\left(\mu_{i}-\mu_{\text {harapan }}\right)^{2}}{\mu_{\text {harapan }}}$

$\chi^{2}=\frac{0.00522}{0.683}$

$\chi^{2}=0.008$

Berdasarkan nilai batas kritis $\chi^{2}$ dengan taraf nyata $\alpha=$ 0.05 dan $k=5$

Maka $\chi_{(1-\alpha)(k-1)}^{2}=\chi^{2}{ }_{0.95(4)}=0.711$

Sehingga, $\chi_{\text {hitung }}^{2} \leq \chi_{\text {tabel }}^{2}=0.008 \leq 0.711$

Maka diterima asumsi bahwa pola pelayanan nasabah diteller IV berdistribusi eksponensial.

H0 : Data yang menyebar dengan sebaran eksponensial

H1 : Data yang tidak mengikuti sebaran eksponensial

Tabel 5. Rata-rata Kecepatan Pelayanan Nasabah Pada Teller V

\begin{tabular}{|c|c|c|c|c|c|}
\hline Hari & Senin & $\begin{array}{c}\text { Selas } \\
\mathrm{a}\end{array}$ & Rabu & $\begin{array}{c}\text { Kami } \\
\mathrm{s}\end{array}$ & $\begin{array}{c}\text { Juma } \\
\mathrm{t}\end{array}$ \\
\hline$\mu$ & 0.401 & 0.449 & 0.312 & 0.231 & 0.276 \\
\hline$\mu_{\text {harapan }}$ & $\begin{array}{c}0.26 \\
8\end{array}$ & 0.286 & 0.228 & 0.183 & 0.209 \\
\hline
\end{tabular}

Dari data tabel 5 maka:

$\chi^{2}=\sum_{i=1}^{k} \frac{\left(\mu_{i}-\mu_{\text {harapan }}\right)^{2}}{\mu_{\text {harapan }}}$

$\chi^{2}=\frac{0.05811}{1.174}$

$\chi^{2}=0.049$

Berdasarkan nilai batas kritis $\chi^{2}$ dengan taraf nyata $\alpha=$ 0.05 dan $k=5$

Maka $\chi_{(1-\alpha)(k-1)}^{2}=\chi^{2}{ }_{0.95(4)}=0.711$

Sehingga, $\chi_{\text {hitung }}^{2} \leq \chi_{\text {tabel }}^{2}=0.049 \leq 0.711$

Maka diterima asumsi bahwa pola pelayanan nasabah pada teller $\mathrm{V}$ berdistribusi eksponensial. H0 : Data yang menyebar dengan sebaran eksponensial H1 : Data yang tidak mengikuti sebaran eksponensial
Tabel 6. Rata-rata Kecepatan Pelayanan Nasabah Pada Teller VI

\begin{tabular}{|c|c|c|c|c|c|}
\hline Hari & Senin & Selasa & Rabu & Kamis & Jumat \\
\hline$\mu$ & 0.134 & 0.165 & 0.159 & 0.167 & 0 \\
\hline$\mu_{\text {harapan }}$ & 0.117 & 0.139 & 0.135 & 0.141 & 0 \\
\hline
\end{tabular}

Dari data tabel 6 maka:

$\chi^{2}=\sum_{i=1}^{k} \frac{\left(\mu_{i}-\mu_{\text {harapan }}\right)^{2}}{\mu_{\text {harapan }}}$

$\chi^{2}=\frac{0.00222}{0.532}$

$\chi^{2}=0.004$

Berdasarkan nilai batas kritis $\chi^{2}$ dengan taraf nyata $\alpha=$ 0.05 dan $k=5$

Maka $\chi_{(1-\alpha)(k-1)}^{2}=\chi^{2}{ }_{0.95(4)}=0.711$

Sehingga, $\chi_{\text {hitung }}^{2} \leq \chi_{\text {tabel }}^{2}=0.004 \leq 0.711$

Maka diterima asumsi bahwa pola kedatangan nasabah pada teller VI berdistribusi eksponensial.

H0 : Data yang menyebar dengan sebaran eksponensial H1 : Data yang tidak mengikuti sebaran eksponensial

Tabel 7. Rata-rata Kecepatan Pelayanan Nasabah Pada Teller VII

\begin{tabular}{|c|c|c|c|c|c|}
\hline Hari & Senin & Selasa & Rabu & Kamis & Jumat \\
\hline$\mu$ & 0.252 & 0.256 & 0.394 & 0.115 & 0.214 \\
\hline$\mu_{\text {harapan }}$ & 0.195 & 0.198 & 0.265 & 0.102 & 0.172 \\
\hline
\end{tabular}

Dari data tabel 7 maka:

$\chi^{2}=\sum_{i=1}^{k} \frac{\left(\mu_{i}-\mu_{\text {harapan }}\right)^{2}}{\mu_{\text {harapan }}}$

$\chi^{2}=\frac{0.02519}{0.932}$

$\chi^{2}=0.027$

Berdasarkan nilai batas kritis $\chi^{2}$ dengan taraf nyata $\alpha=$ 0.05 dan $k=5$

Maka $\chi_{(1-\alpha)(k-1)}^{2}=\chi^{2}{ }_{0.95(4)}=0.711$

Sehingga, $\chi^{2}{ }_{\text {hitung }} \leq \chi_{\text {tabel }}^{2}=0.027 \leq 0.711$

Maka diterima asumsi bahwa pola kedatangan nasabah pada teller VII berdistribusi eksponensial. H0 : Data yang menyebar dengan sebaran eksponensial H1 : Data yang tidak mengikuti sebaran eksponensial

Tabel 8. Rata-rata Kecepatan Pelayanan Nasabah Pada Teller VIII

\begin{tabular}{|c|c|c|c|c|c|}
\hline Hari & Senin & Selasa & Rabu & Kamis & Jumat \\
\hline$\mu$ & 0.126 & 0.219 & 0.090 & 0.222 & 0.130 \\
\hline$\mu_{\text {harapan }}$ & 0.111 & 0.175 & 0.082 & 0.177 & 0.114 \\
\hline
\end{tabular}

Dari data tabel 8 maka:

$\chi^{2}=\sum_{i=1}^{k} \frac{\left(\mu_{i}-\mu_{\text {harapan }}\right)^{2}}{\mu_{\text {harapan }}}$

$\chi^{2}=\frac{0.00451}{0.659}$

$\chi^{2}=0.006$ 
Berdasarkan nilai batas kritis $\chi^{2}$ dengan taraf nyata $\alpha=$ 0.05 dan $k=5$

Maka $\chi_{(1-\alpha)(k-1)}^{2}=\chi^{2}{ }_{0.95(4)}=0.711$

Sehingga, $\chi_{\text {hitung }}^{2} \leq \chi_{\text {tabel }}^{2}=0.006 \leq 0.711$

Maka diterima asumsi bahwa pola kedatangan nasabah pada teller VIII berdistribusi eksponensial.

H0 : Data yang menyebar dengan sebaran eksponensial

H1 : Data yang tidak mengikuti sebaran eksponensial

\section{Hasil Analisis Sistem Antrian Dengan Menggunakan Antrian Jalur Berganda}

- Jumlah Kedatangan Rata-rata Persatuan Waktu $(\lambda)$ $\lambda=\frac{\text { Total Kedatangan }}{\text { Waktu Pengamatan }}$

$\lambda=\frac{421}{10}$

$\lambda=42.1$ nasabah per jam, $\quad \frac{42.1}{60}=0.7$ nasabah yang datang per menit.

Nilai tersebut menunjukkan kedatangan rata-rata nasabah adalah 42 nasabah yang datang per jam atau 0.7 nasabah per menit.

- Jumlah Rata-rata Orang Yang Dilayani Persatuan Waktu $(\mu)$

Dari tabel 2-8, diperoleh jumlah rata-rata kecepatan waktu pelayanan $=7.047$ nasabah per menit maka:

$$
\begin{aligned}
& \mu=\frac{1}{\text { Rata }- \text { rata Kecepatan Waktu Pelayanan }} \\
& \mu=\frac{1}{7.047} \\
& \mu=0.142 \text { nasabah dilayani per menit, } \\
& 0.142 \times 60=8.52 \text { nasabah dilayani per jam. }
\end{aligned}
$$

Nilai tersebut menunjukkan rata-rata orang yang dilayani adalah 9 nasabah per jam atau 0.142 nasabah per menit.

1) Probabilitas terdapat o orang dalam sistem / tidak adanya pelanggan dalam sistem $(\mathrm{Po})$

$$
P o=\frac{1}{\left[\sum_{n=0}^{M-1} \frac{1}{n !}\left(\frac{\lambda}{\mu}\right)^{n}\right]+\frac{1}{M !}\left(\frac{\lambda}{\mu}\right)^{M} \frac{M \mu}{M \lambda-\mu}}
$$$$
P o=0.01
$$

2) Jumlah pelanggan rata-rata dalam sistem $(L s)$

$$
\begin{aligned}
& L s=\frac{\lambda \mu(\lambda / \mu)^{M}}{(M-1) !(M \mu-\lambda)^{2}} \text { Po }+\frac{\lambda}{\mu} \\
& L s=6.1 \text { nasabah } \\
& \text { Nilai tersebut menunjukkan jumlah rata-rata } \\
& \text { nasabah yang berada dalam sistem ada } 6 \text { nasabah. }
\end{aligned}
$$

3) Waktu rata-rata yang dihabiskan seorang pelanggan dalam antrian dan sedang dilayani $(W s)$

$$
\begin{aligned}
W s & =\frac{L s}{\lambda} \\
W s & =8.7 \text { menit }
\end{aligned}
$$

Nilai tersebut menunjukkan bahwa waktu rata-rata nasabah yang menunggu dalam sistem selama 8-9 menit.

4) Jumlah orang atau unit rata-rata yang menunggu dalam antrian $(L q)$

$$
\begin{aligned}
& L q=L s-\frac{\lambda}{\mu} \\
& L q=1.2 \text { nasabah }
\end{aligned}
$$

Nilai tersebut menunjukkan bahwa jumlah rata-rata nasabah yang menunggu dalam antrian ada 1 nasabah.

5) Waktu rata-rata yang dihabiskan oleh seorang pelanggan atau unit untuk menunggu dalam antrian $(W q)$

$$
\begin{aligned}
& W q=\frac{L q}{\lambda} \\
& W q=1.7 \text { menit }
\end{aligned}
$$

Nilai tersebut menunjukkan bahwa waktu rata-rata yang dihabiskan nasabah untuk menunggu dalam antrian selama 1-2 menit.

\section{KESIMPULAN DAN SARAN \\ Kesimpulan}

1. Model teori antrian di PT. Bank Negara Indonesia (Persero) Tbk. Kantor Cabang Manado adalah Model B: M/M/S (Multiple Channel Query System Atau Model Antrian Jalur Berganda), jumlah teller yang beroperasi ada 7 teller dan pelayanan yang digunakan adalah secara First Come First Served. Tingkat kedatangan nasabah berdistribusi Poisson sedangkan waktu pelayanan nasabah berdistribusi eksponensial.

2. Karakteristik panjang antrian di PT. Bank Negara Indonesia (Persero) Tbk. Kantor Cabang Manado dengan menggunakan model antrian jalur berganda adalah jumlah kedatangan rata-rata sebanyak 42 nasabah yang datang per jam dan jumlah rata-rata orang dilayani ada 9 nasabah dilayani per jam. Tidak adanya pelanggan dalam sistem o.01. Jumlah pelanggan rata-rata dalam sistem sebanyak 6 nasabah. Waktu rata-rata yang dihabiskan seorang pelanggan dalam antrian dan sedang dilayani (Dalam sistem) 8-9 menit. Jumlah rata-rata nasabah yang menunggu dalam antrian ada 1 nasabah. Waktu rata-rata yang dihabiskan oleh nasabah untuk menunggu dalam antrian 1-2 menit. Dari hasil kesimpulan diatas maka tingkat kedatangan nasabah lebih cepat dibandingkan dengan kecepatan waktu pelayanan di teller, sehingga terjadi antrian yang cukup lama.

\section{Saran}

1. Berdasarkan hasil penelitian bahwa jumlah kedatangan lebih cepat dibandingkan dengan kecepatan waktu pelayanan, untuk itu sebaiknya fasilitas jumlah teller dapat ditambahkan agar pelayanan lebih cepat dan nasabah yang menunggu tidak terlalu lama.

2. Model struktur antrian tidak hanya Multi Channel Single Phase. Sehingga untuk penelitian selanjutnya dapat membahas mengenai struktur antrian yang lain, misalnya Multi Channel Multi Phase.

\section{REFERENSI}

[1] Saladin, D. 2007. Manajemen Pemasaran. Bandung: Linda Karya. 
[2] Larson, R.C. 1987. Perspectives on Queues: Social Justice and the Psychology of Queueing. Journal of Service Research. 35(6) : 895-905.

[3] Hui, M.K., and D.K., Tse. 1996. What to Tell Consumers in Waits of Different Lengths: An Integrative Model of Service Evaluation. Journal of Marketing. 6o(2) : 81-90.

[4] Hana, S., M. Paendong., dan T. Manurung. 2012. Deskripsi Sistem Antrian Pada Bank Sulut Manado. Jurnal d'Cartesian. 1(1) : 3744.

[5] Salaki, T.S. 2012. Deskripsi Sistem Antrian Pada Klinik Dokter Spesialis Penyakit Dalam. Jurnal Ilmiah Sains. 12(1) : 72-76.

[6] Sumarno M., Y. Langi., dan L. Latumakulita. 2015. Model Antrian Pada Sistem Pembayaran di Golden Pasar Swalayan Manado. Jurnal d' Cartesian. 4(2) : 180-187.

[7] Kakiay, T.J. 2004. Dasar Teori Antrian untuk Kehidupan Nyata. Penerbit Andi. Yogyakarta.

[8] Hilier, L. 2008. Introduction to Operations Research, jilid 2. Penerbit Andi. Yogyakarta.

[9] Bronson, R., dan J. Hans. 1988. Teori dan SoalSoal Operation Research, seri buku Schaum's. Erlangga. Jakarta.

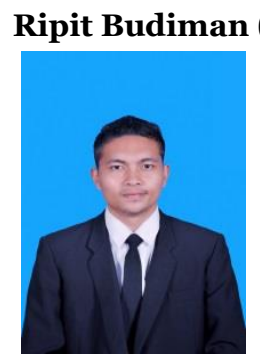

ipitbudiman97@gmail.com)

lahir dan tinggal di Karungo, Kecamatan Biaro, Kabupaten Siau Tagulandang dan Biaro, Sulawesi utara. Menempuh pendidikan tinggi Program Studi Matematika dan Ilmu Pengetahuan Alam Universitas Sam Ratulangi Manado. Tahun 2019 adalah tahun terakhir ia menempuh studi. Makalah ini merupakan hasil penelitian skripsinya yang di publikasikan.

Djoni Hatidja (dhatidja@unsrat.ac.id)

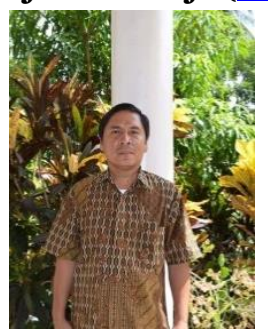

Pada tahun 1994, memperoleh gelar sarjana di Program Studi Matematika, Institut Pertanian Bogor. Gelar Magister Sains diperoleh dari Institut Pertanian Bogor pada tahun 2000. Menjadi dosen di Jurusan Matematika, FMIPA, Universitas Sam Ratulangi Manado sejak 2000 sampai yang ditekuni yaitu Statistika.
Marline Paendong (marline paendong@yahoo.com)

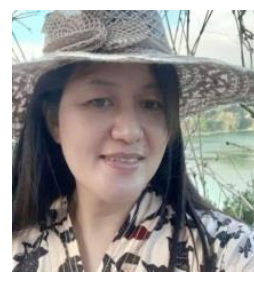
Pada tahun 1999, memperoleh gelar sarjana di Program Studi Matematika, Universitas Gadjah Mada. Gelar Magister Sains diperoleh di Institusi Pertanian Bogor pada tahun 2006. Menjadi dosen di Jurusan matematika, FMIPA, Universitas Sam Ratulangi. 